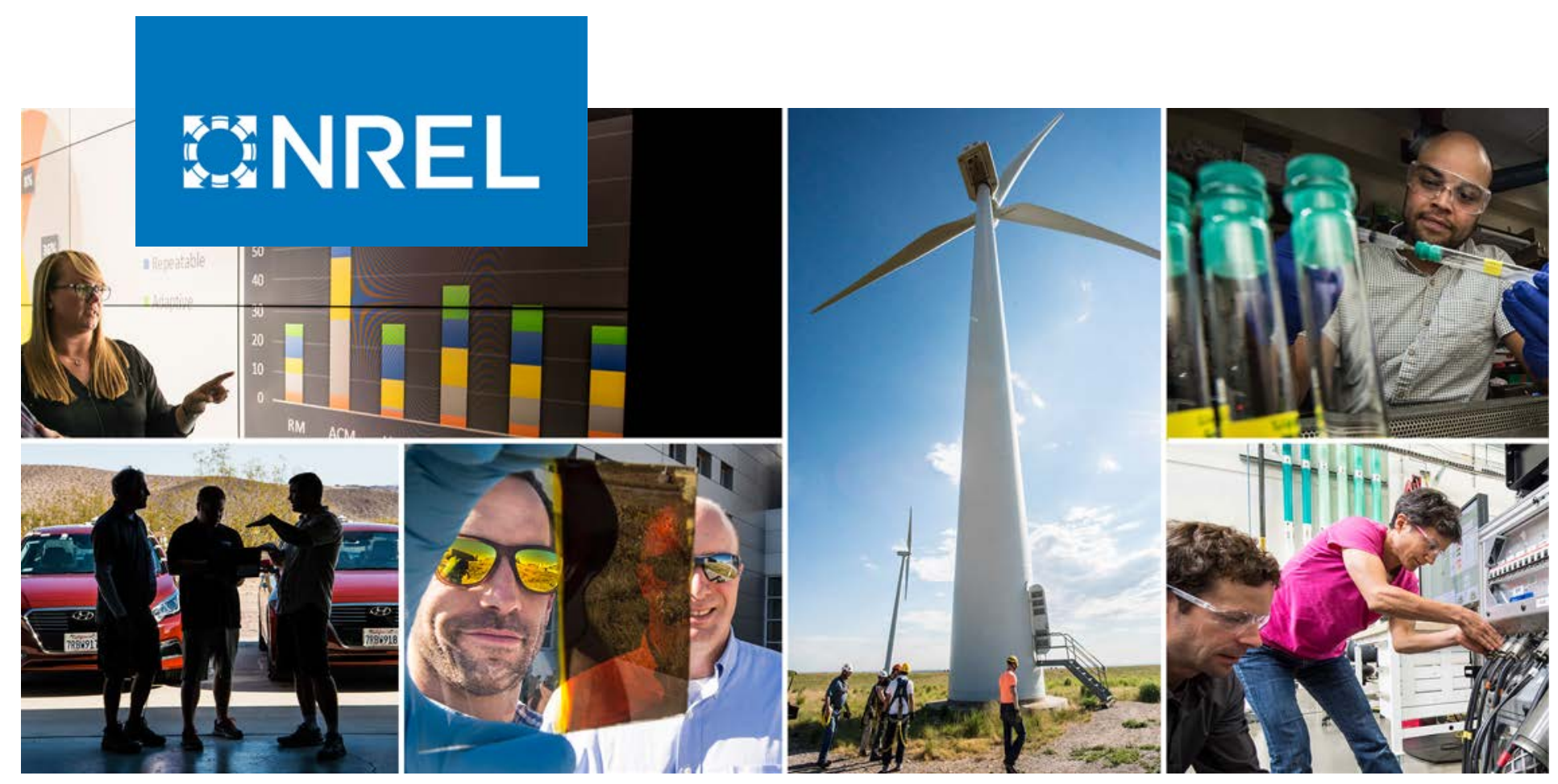

\title{
Sustainability of the U.S. Manufacturing Sector: Use of the United Nations Sustainable Development Goals
}

Jes Stershic, Tsisilile Igogo, and Alberta Carpenter

National Renewable Energy Laboratory

NREL is a national laboratory of the U.S. Department of Energy Office of Energy Efficiency \& Renewable Energy

Operated by the Alliance for Sustainable Energy, LLC

This report is available at no cost from the National Renewable Energy Laboratory (NREL) at www.nrel.gov/publications.
Technical Report

NREL/TP-6A20-80732

December 2021 


\section{GNREL}

\section{Sustainability of the U.S. Manufacturing Sector: Use of the United Nations Sustainable Development Goals}

Jes Stershic, Tsisilile Igogo, and Alberta Carpenter

National Renewable Energy Laboratory

\section{Suggested Citation}

Stershic, Jes, Tsisilile Igogo, and Alberta Carpenter. 2021. Sustainability of the U.S. Manufacturing Sector: Use of the United Nations Sustainable Development Goals. Golden, CO: National Renewable Energy Laboratory.

https://www.nrel.gov/docs/fy22osti/80732.pdf.

NREL is a national laboratory of the U.S. Department of Energy Office of Energy Efficiency \& Renewable Energy Operated by the Alliance for Sustainable Energy, LLC

This report is available at no cost from the National Renewable Energy Laboratory (NREL) at www.nrel.gov/publications.

Contract No. DE-AC36-08GO28308
Technical Report

NREL/TP-6A20-80732

December 2021

National Renewable Energy Laboratory 15013 Denver West Parkway Golden, CO 80401 303-275-3000 • www.nrel.gov 


\section{NOTICE}

This work was authored by the National Renewable Energy Laboratory, operated by Alliance for Sustainable Energy, LLC, for the U.S. Department of Energy (DOE) under Contract No. DE-AC36-08GO28308. Funding provided by the U.S. Department of Energy Office of Energy Efficiency and Renewable Energy Advanced Manufacturing Office. The views expressed herein do not necessarily represent the views of the DOE or the U.S. Government. The content of this publication has not been approved by the United Nations and does not reflect the views of the United Nations or its officials or Member States.

This report is available at no cost from the National Renewable Energy Laboratory (NREL) at www.nrel.gov/publications.

U.S. Department of Energy (DOE) reports produced after 1991 and a growing number of pre-1991 documents are available free via www.OSTI.gov.

Cover Photos by Dennis Schroeder: (clockwise, left to right) NREL 51934, NREL 45897, NREL 42160, NREL 45891, NREL 48097, NREL 46526.

NREL prints on paper that contains recycled content. 


\section{Acknowledgments}

The authors are greatly indebted to several individuals for their support and guidance. We wish to thank Daniel Bilello, Emily Newes, Darlene Steward, and Matt Ringer at the National

Renewable Energy Laboratory, and Joe Cresko at the Advanced Manufacturing Office. And we wish to thank Moriah Petty, Liz Breazeale, and Fred Zietz for the communications, design, and editing support. Any errors or omissions are solely the responsibility of the authors. 


\section{List of Acronyms}

AMO

BEA

DOE

GHG

MYPP

NAM

QTR

RDD\&D

SDG

TA

UN
Advanced Manufacturing Office

Bureau of Economic Analysis

U.S. Department of Energy

greenhouse gas

Multi-Year Program Plan

National Association of Manufacturers

Quadrennial Technology Review

research, development, demonstration, and deployment

Sustainable Development Goal

Technology Assessment

United Nations 


\section{Executive Summary}

The United Nations' 17 Sustainable Development Goals (SDGs) aim to improve health and education, reduce inequality, and encourage economic growth, while also preserving or improving the conditions of our oceans and forests. Pursuing these SDGs would mean \$12 trillion in economic opportunities, while also improving the lives of all people and bettering the planet. Some manufacturing companies are already focusing on sustainability, but not all. In 2019, almost 30\% of National Association of Manufacturers members did not have a sustainability policy, goals, or program in place.

Business drivers for sustainability and the SDGs are similar, with focuses on economic growth and consumer demands. Despite the shortcomings of the SDGs, they represent an opportunity for manufacturing companies to communicate their sustainability strategies and account for impacts of their sustainability actions.

This report evaluates the SDGs and the manufacturing sector. The manufacturing sector was analyzed using the technology assessments (TAs) introduced in the 2015 Quadrennial Technology Review (QTR) review, which focused on concepts, challenges, and solutions to meet the United States' energy needs. Research, development, demonstration, and deployment (RDD\&D) in the TA areas by companies were collected and then their sustainability reporting was analyzed for mentions of the SDGs. The call-out boxes throughout this report provide examples of the RDD\&D efforts.

The possible overlap between the SDGs and the Advanced Manufacturing Office (AMO) was also evaluated. Direct and likely relationships between the SDGs and the TAs were established by utilizing the draft Multi-Year Program Plan (MYPP) for Fiscal Years 2017-2021. Positives, challenges, SDG-related literature, and future steps are also discussed in this report. 


\section{Table of Contents}

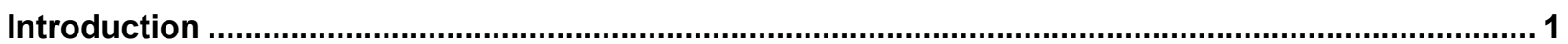

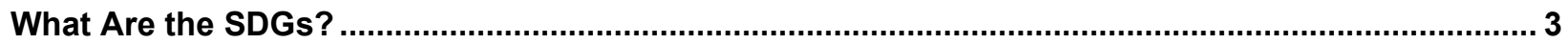

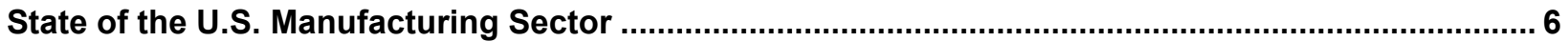

Data Collection .......................................................................................................................... 7

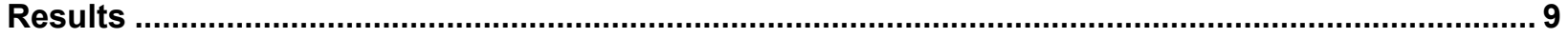

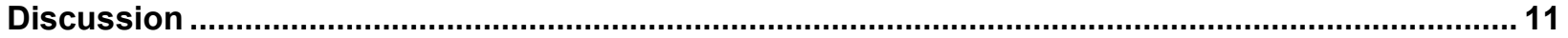

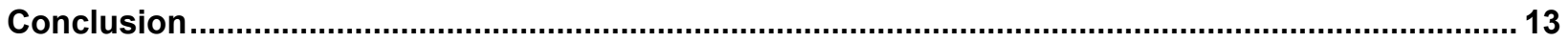

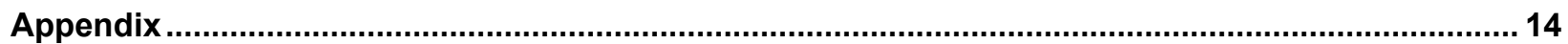

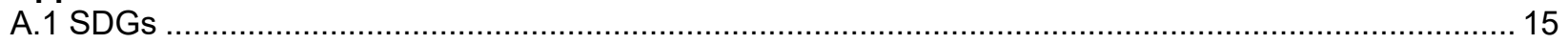

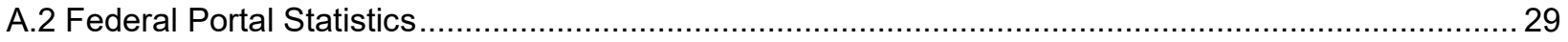

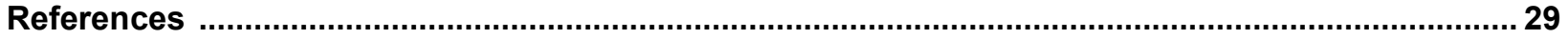




\section{List of Figures}

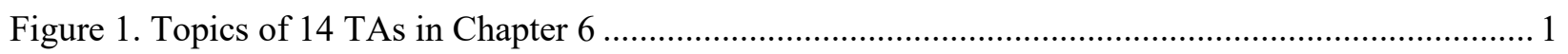

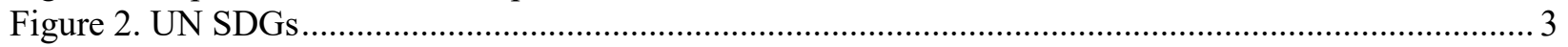

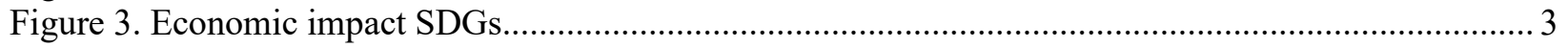

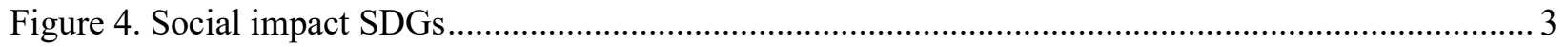

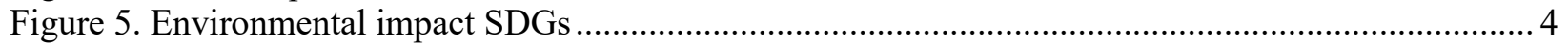

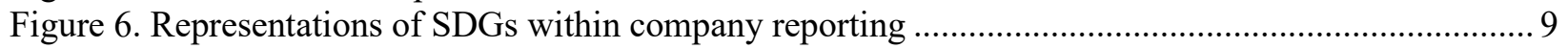

Figure 7. Heat map of relationships between draft MYPP and SDGs ................................................... 9

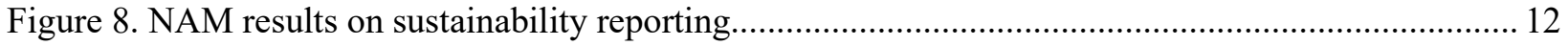

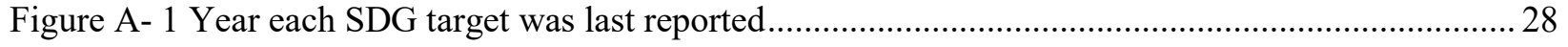

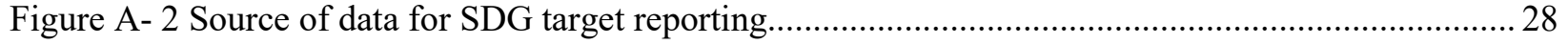




\section{Introduction}

The U.S. Environmental Protection Agency defines sustainable manufacturing as "the creation of manufactured products through environmentally-sound processes that minimize negative environmental impacts while conserving energy and natural resources" (United States Environmental Protection Agency 2020). Slowing the effect of negative environmental impacts will allow the needs of the current generation to be met while giving future generations the ability to meet their needs as well (World Commission on Environment and Development 1987). The U.S. Department of Energy (DOE) has committed to ensuring America's security and prosperity, and sustainable manufacturing is a large part of the nation's continued success (U.S. Department of Energy 2021a).

In 2015, DOE released the Quadrennial Technology Review (QTR), which reviewed "the most promising RDD\&D opportunities across energy technologies to effectively address the nation's energy needs" (U.S. Department of Energy 2021c). The QTR focused on concepts, challenges, and solutions to the energy needs. Chapter 6 of the report-Innovating Clean Energy Technologies in Advanced Manufacturing-focused on how to evaluate and improve the sustainability of manufacturing. Individual and unit manufacturing processes, facilities where the goods are produced, and manufacturing supply chains are evaluated closely in Chapter 6 . The energy impacts and use of materials in each stage of the product life cycle are examined as well. The Sustainable Manufacturing-Flow of Materials (6L) through Industry Technology Assessment (TA) was one of 14 TAs covering a range of interconnected innovative clean energy technology topics (Figure 1).

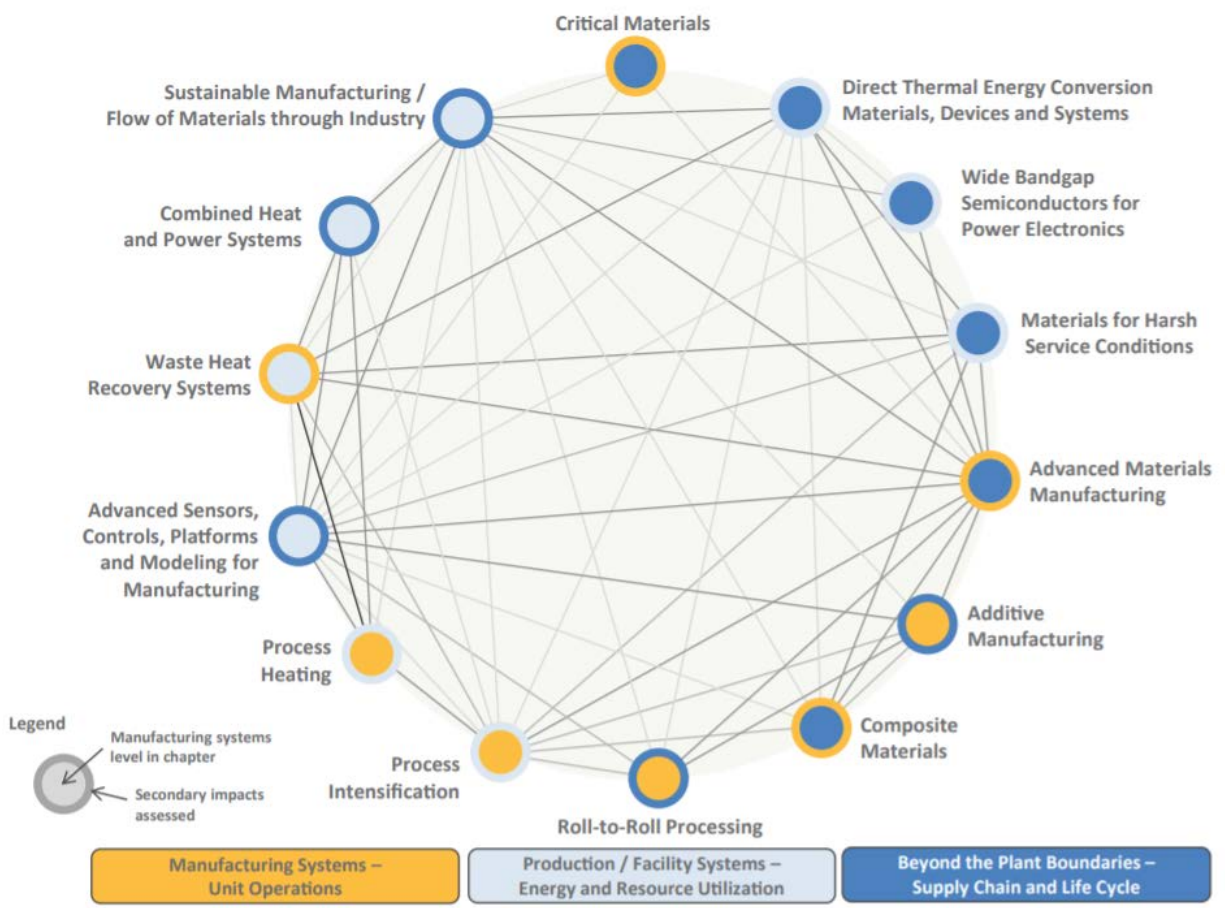

Figure 1. Topics of 14 TAs in Chapter 6

Source: (U.S. Department of Energy, 2015a) 
TA 6L relates to the other TA topics, as well as to electric power, buildings, fuels, and transportation. TA $6 \mathrm{~L}$ notes that while manufacturing systems have traditionally been linear, from material extraction to production to consumer use to landfill disposal, they do not have to be linear. They can incorporate remanufacturing, reuse by consumers, deconstruction, and finally

\begin{tabular}{|l|}
\hline Manufacturing and the SDGs \\
Alcoa introduced predictive \\
maintenance, using Oracle's \\
enterprise asset management, to \\
look at raw manufacturing data \\
and help point out failures before \\
they occur. One sensor showed \\
an idling current, indicating a \\
belt guard had come loose. Alcoa \\
was able to fix the loose belt \\
guard and it saved the plant over \\
11 hours of unplanned downtime \\
(Kennedy 2020). Alcoa's work \\
in this example relates to SDGs \\
8,9 , and 17. \\
\hline
\end{tabular}
disposal. TA 6L evaluates technologies and trends in the different scales of the manufacturing process. Trends of the sector, methods to reach greater material and energy efficiency, and current Advanced Manufacturing Office (AMO) approaches are a few of the topics covered in TA 6L (U.S. Department of Energy 2015b).

Manufacturing and RDD\&D efforts further the United Nations (UN) Sustainable Development Goals (SDGs). The SDGs are a collection of 17 goals with 169 targets that aim to improve health and education, reduce inequality, and encourage economic growth, while also preserving or improving the conditions of our oceans and forests (United Nations n.d.).

The SDGs provide a commonly used international language to discuss the impact a company has with investors, consumers, and international colleagues (Prakash et al. 2017). They represent a $\$ 12$ trillion economic opportunity for the companies who are early movers, and they provide companies an opportunity to look at all aspects of their business (Business and Sustainable Development Commission 2017). Further informing companies about the benefits of the incorporating SDGs could help make them more efficient, competitive, and productive.

The rest of this report will provide an overview of the SDGs, the manufacturing landscape, and how the two can continue growing together. 


\section{What Are the SDGs?}

The UN SDGs are a continuation of the Millennium Development Goals set forth in 2000 . Agreed upon by all Member States, the Millennium Development Goals were eight goals that focused on eradicating extreme poverty by 2015. In 2012, the Member States decided to further these goals and expand them to include other matters, including the economy, energy, and many others. During the UN Sustainable Development Summit in September 2015, 17 SDGs were adopted (United Nations n.d.).

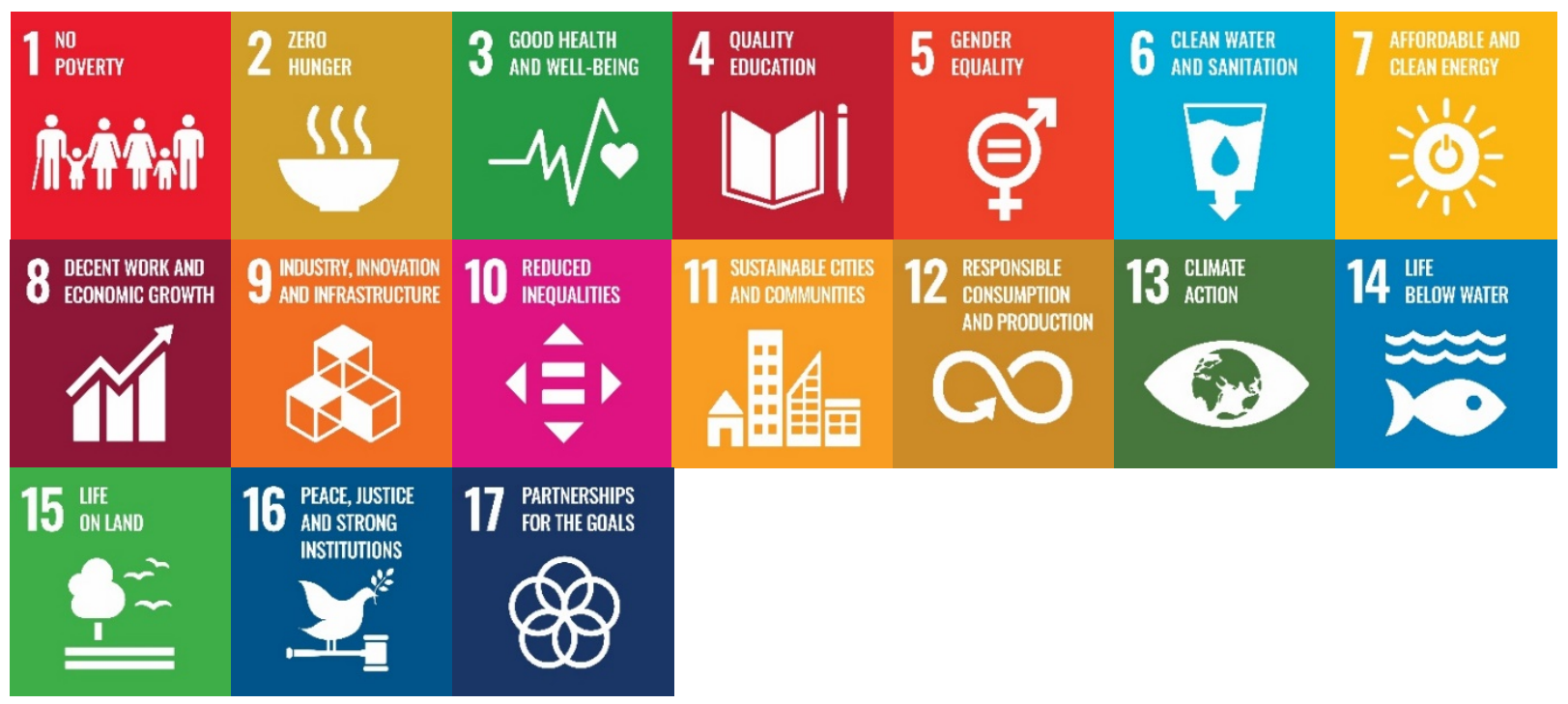

Figure 2. UN SDGs

Source: (United Nations 2021a)

The World Economic Forum grouped these 17 SDGs into three groups: economic impacts, social impacts, and environmental impacts.

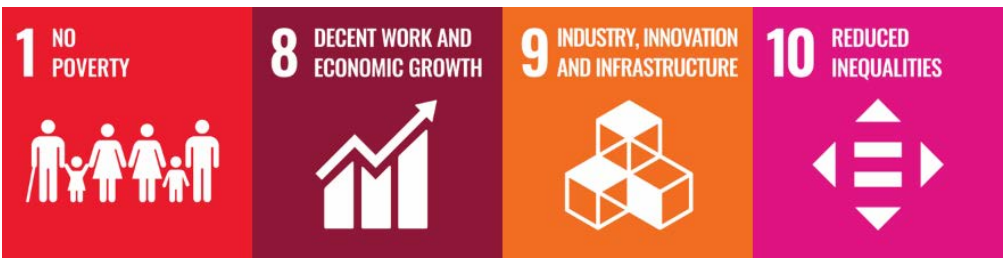

Figure 3. Economic impact SDGs

Source: (World Economic Forum 2018)

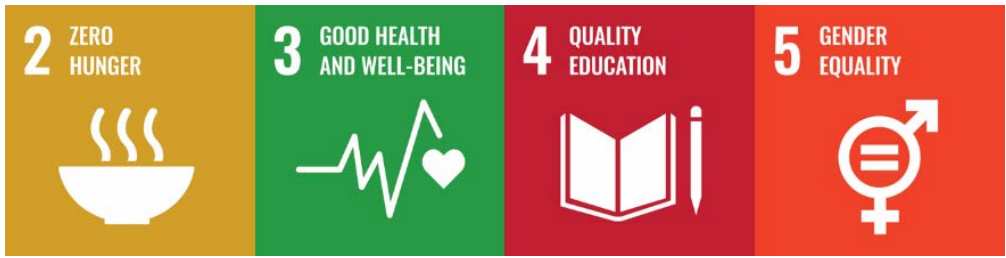

Figure 4. Social impact SDGs

Source: (World Economic Forum 2018) 


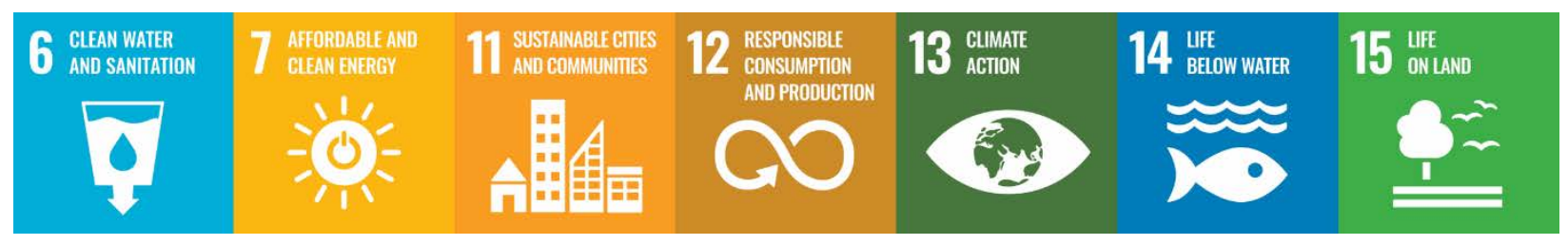

Figure 5. Environmental impact SDGs

Source: (World Economic Forum 2018)

Goals 16 and 17 are not included in an impact group because they are overarching. Each of these SDGs have targets, or more specific intentions within the goal. As an example, SDG 7 is "Ensure access to affordable, reliable, sustainable and modern energy for all" and Target 7.1 is "By 2030, ensure universal access to affordable, reliable and modern energy services" (United Nations 2021b). Appendix A1 lists the SDGs and targets.

A 2017 PricewaterhouseCoopers report states that the most important SDGs for manufacturing are SDGs 7, 8, 9, 12, and 13 (PwC 2017). These five SDGs identified by

PricewaterhouseCoopers are in the economic and

environmental impact groupings. This is just one report,

which may not be fully representative of all

manufacturing. There are different perspectives on how to track progress on the SDGs and targets, the UN provides indicators or ways to measure the targets. Public tools, private tools, and frameworks also exist to help companies measure their targets (Johnsson et al. 2020; SDSN n.d.). Companies can also individually track their progress towards the SDGs and targets. For example, Microsoft is supporting projects in North America and Asia, which provide $1.6 \mathrm{GW}$ of electricity, and have renewable energy as a focus of their power purchase agreements (Art and Emejulu 2020). Microsoft linked these actions to SDG 7 (affordable and clean energy).

As sustainable reporting is not mandated, there is no set method for what needs to be reported. This applies to the SDGs as well. It is easy for companies to only report or publicize the SDGs they are doing well in (Johnsson et al. 2020). Alongside only reporting successes with the SDGs, companies are often reporting a metric that they can measure instead of a metric that is directly applicable to the SDG target (Hak et al. 2016). Some SDGs and their

\section{Manufacturing and the SDGs}

To decrease their water use, Ford has invested in several technology and process improvements. The first set of improvements is membrane biological reactors and reverseosmosis processes, which allow them to recycle water from onsite wastewater treatment plants in arid regions. Ford also uses minimum quantity lubrication, allowing them to use a very small amount of oil to machine, instead of the traditional machining processes, which require significant amounts of metal-working fluids and water. (Ford 2020) Ford is pursuing SDGs 6, 8, and 12 with this work. targets are more sensitive to the calculation method than others, with one study showing how varying countries scored differently on the SDGs based on their calculation method (Miola and Schiltz 2019). The authors did not find any peer reviewed literature about how well companies are meeting their own internal SDG metrics.

The SDGs and their supporting principles have been around for almost 20 years, yet some researchers still believe they could be more finely tuned. $17 \%$ of the SDG targets were said to 
need "significant work," while only $29 \%$ of the targets were said to be "well developed" (Hak et al. 2016). Finally, some SDGs may be interlinked, so progress in one SDG may help or hinder progress in another SDG (Naidoo and Fisher 2020; Schroeder et al. 2019). For example, to help support gender equality (SDG 5), greater job opportunities and economic growth need to take place (SDG 8) (Chapa n.d.). Alternatively, working toward zero hunger (SDG 2) may require increased land use and possible degradation (SDG 15) (Schroeder et al. 2019).

Manufacturing and the SDGs
Collins Bus, part of Rev Group,
created a new design for an all-
electric school bus. The all-
electric aspect of the bus means
lower emissions, helping
decrease driver fatigue.
Additionally, all-electric means
the buses do not use as many
moving parts as traditional gas
or diesel buses, which can save
customers up to $85 \%$ savings in
operating and maintenance
costs (Rev Group, Inc. 2020).
Electric buses and healthier
drivers relate to SDGs $3,7,8,9$,
11,12 .

\section{Manufacturing and the SDGs}

Collins Bus, part of Rev Group, created a new design for an allelectric school bus. The alllower emissions, helping decrease driver fatigue. Additionally, all-electric means the buses do not use as many moving parts as traditional gas or diesel buses, which can save customers up to $85 \%$ savings in operating and maintenance Electric buses and healthier 11,12 .
Despite the shortcomings listed above, the SDGs provide many positives. The first one is their level of international acceptance. All 193 member states of the UN agreed to adopt the SDGs, providing a common language that has been in development for over 20 years (United Nations 2021c). The common language allows companies, cities, and even individuals to communicate clearly (Prakash et al. 2017; Ike et al. 2019). Individuals, as well as company stakeholders, can now see the manufacturing companies using a common language, reporting goals, and can build confidence knowing these companies are using a worldrecognized standard of sustainability (Business and Sustainable Development Commission 2017). Overall, as environmental reporting and standards are pushed more heavily in the industry, the SDGs are a group of established targets and metrics that management teams can use (Khan et al. 2021). 


\section{State of the U.S. Manufacturing Sector}

The manufacturing sector is an integral part of the U.S. economy, providing goods, services, and jobs to the country and the world. Full-time and part-time employment in the manufacturing sector was on a steady incline from 2010 to 2019, down from a peak in 1979 (U.S. Bureau of Economic Analysis n.d.). The real wages of manufacturing workers has experienced slower growth than the private sector, but the average hourly wage in 2018 was $\$ 21.54$ which is almost three times higher than the national minimum wage in 2018 (Harris \& McCall 2019). The manufacturing sector has contributed to the growth of the U.S. economy since the Bureau of Economic Analysis (BEA) started tracking the sector back in the late 1940s. The BEA has tracked increases in gross output ${ }^{1}$ over the last seven decades, which can be attributed to multiple factors, including increased efficiencies, updated production methods, outsourcing, automation, and inflation. As a portion of the overall economy, the sector has had a roughly constant share of real GDP from the 1940s through 2015, ranging from 11\% to 14\% (Chien \& Morris 2017).

Manufacturing sector activities may also be represented by other metrics, such as greenhouse gas (GHG) emissions, energy consumption, and water consumption. While not an indicator of the

\section{Manufacturing and the SDGs}

Febreze, a Proctor and Gamble company, introduced a new spray bottle packaging design. The spray bottle now has a reusable spray head, and the bottom of the bottle is made from plastic type 7 , which is fully recyclable. In addition to these design changes, the spray no longer contains any chemical propellants. (Reynolds 2018)

This healthier and environmentally friendly design relates to SDGs 3, 6, 8, 12 .

health of the sector, GHG emissions can be an indicator of the adoption of new sustainable practices and a shift toward a greener economy.

Since the late 1990s, GHG emissions are down across the industrial sector (U.S. Environmental Protection Agency 2021). In fact, the amount of GHG emissions per billion dollars of industrial sector output has decreased almost 60\% since 1990 (U.S. Environmental Protection Agency 2021). This decrease in emissions has been facilitated by multiple factors, including DOE investing in energy efficiency technologies, companies adopting those energy efficiency technologies, and an increase in the amount of renewable energy consumed (U.S. Energy Information Administration 2021b; U.S. Department of Energy 2021b; U.S. Energy Information Administration 2021a).

As a portion of primary energy ${ }^{2}$, renewable energy is continuing to grow, from about $4 \%$ to over $10 \%$ of the supply between 1949 and 2020 (U.S. Energy Information Administration 2021b). As energy efficiency and the amount of renewable energy consumed increase, GHG emissions will likely continue to fall. The United States Geological Survey data has indicated that U.S. industrial water consumption has decreased, but better data on a regional, subsector, facility, and activity level is required to understand what the drivers are (United States Geological Survey 2015).

\footnotetext{
${ }^{1}$ Gross output is revenue from the production of products (U.S. Bureau of Economic Analysis 2021).
${ }^{2}$ Primary energy is energy in the form that it is first accounted for in a statistical energy balance, before any

${ }^{1}$ Gross output is revenue from the production of products (U.S. Bureau of Economic Analysis 2021).
${ }^{2}$ Primary energy is energy in the form that it is first accounted for in a statistical energy balance, before any transformation to secondary or tertiary forms of energy (U.S. Energy Information Administration n.d.).
} 


\section{Data Collection}

Along with RDD\&D examples, SDGs in the manufacturing sector and relationships to the draft 2017-2021 AMO Multi-Year Program Plan (MYPP) were reviewed. An existing federal portal highlighting the progress toward each SDG and target was also analyzed (U.S. Office of Management and Budget et al. n.d.).

Companies who were mentioned while reading about the RDD\&D areas highlighted in the QTR were collected. This was the basis for finding the connection between SDGs and manufacturing. The gathered companies and examples are not all-inclusive and represent a small section of the manufacturing sector.

The identified companies' annual or sustainability reports were used to collect SDG data. If a company mentioned a specific SDG or a target within the report, it was counted as represented within the report. For example, if a company mentioned SDG 3.3 one time and 3.4 two times, the SDGs were counted as being represented twice, not three times, as only two SDGs and targets were represented. An overall count of specific mentions was not included. No other types of reports or published materials were considered. If a company did not provide an annual report, then they were not included in the overall count of the SDGs. For example, General Electric reported 433 new suppliers, which passed their global audit, and in 2020 and they linked this action to SDG 8 (decent work and economic growth) (GE 2021). Cummins Inc. said they received 312 patents in 2020 , and linked this fact with SDG 9 (industry, innovation, and infrastructure) (Cummins Inc 2021). These two companies explicitly linked their actions to the SDGs and thus they were included in the analysis.

To evaluate work that AMO is already doing to advance the SDGs, the MYPP was used as a representative document. The 17 TAs used in the QTR are mentioned in the MYPP too. Each TA in the MYPP includes an overview and an AMO approach with specific targets to meet. Direct and likely relationships were found between the SDGs and TAs in the MYPP. Direct relationships were counted if the TA targets had similar wording to the SDGs. Likely relationships between the SDGs and TA targets were counted if similar wording was found within the TA overview. For example, in the draft MYPP, TA 1 is Critical Materials (Advanced Manufacturing Office 2016). AMO target 1.4 is to "recover and recycle materials from end-of-life [EOL] products and manufacturing waste...," which directly relates to SDG 12.5 , "By 2030, substantially reduce waste generation through prevention, reduction, recycling, and reuse." An example of a likely relationship can be found between SDG 9 (industry, innovation, and infrastructure) and this sentence in a TA overview: "Reliable supply chains of materials critical to clean energy technologies are essential to supporting innovation in U.S. manufacturing and enhancing U.S. energy security." While there may be other likely relationships aside from those mentioned in the TA overview, only those that clearly shared wording between the SDG and TA overview were counted. 
The U.S. government also tracks the SDGs. The reporting status, source of data, and date of last update of the SDGs and indicators were taken from an existing portal (U.S. Office of Management and Budget et al. n.d.). This database is a collaboration between the U.S. Office of Management and Budget, Office of Information and Regulatory Affairs, U.S. Department of State, Office of International Organizations, U.S. General Services Administration, and the U.S. Office of Science and Technology Policy. The SDGs stated in manufacturing reports, AMO and DOE representative documents, and the existing portal were used together to create an understanding of SDGs and the manufacturing sector. 


\section{Results}

66 companies across the manufacturing sector were identified as performing work toward one of the QTR RDD\&D topics. Of those 66 companies identified, 22 of them mentioned specific SDGs or targets in their reporting. Figure 6 is a summary showing how many reports had an SDG or target represented. One report could have more than one SDG represented.

\section{Sustainable Development Goals}

\begin{tabular}{|l|c|c|c|c|c|c|c|c|c|c|c|c|c|c|c|c|c|}
\hline & 1 & 2 & 3 & 4 & 5 & 6 & 7 & 8 & 9 & 10 & 11 & 12 & 13 & 14 & 15 & 16 & 17 \\
\hline Number of representations & 8 & 5 & 17 & 16 & 14 & 11 & 19 & 21 & 15 & 15 & 14 & 20 & 17 & 5 & 7 & 10 & 12 \\
\hline
\end{tabular}

Figure 6. Representations of SDGs within company reporting

The reporting of manufacturing companies represented SDGs 7 (affordable and clean energy), 8 (decent work and economic growth), and 12 (responsible consumption and production) the most. SDGs 15 (life on land), 14 (life below water), and 2 (zero hunger) were the least represented.

A heat map of an interpretation of direct and likely relationships between the MYPP and the SDGs is shown in Figure 7.

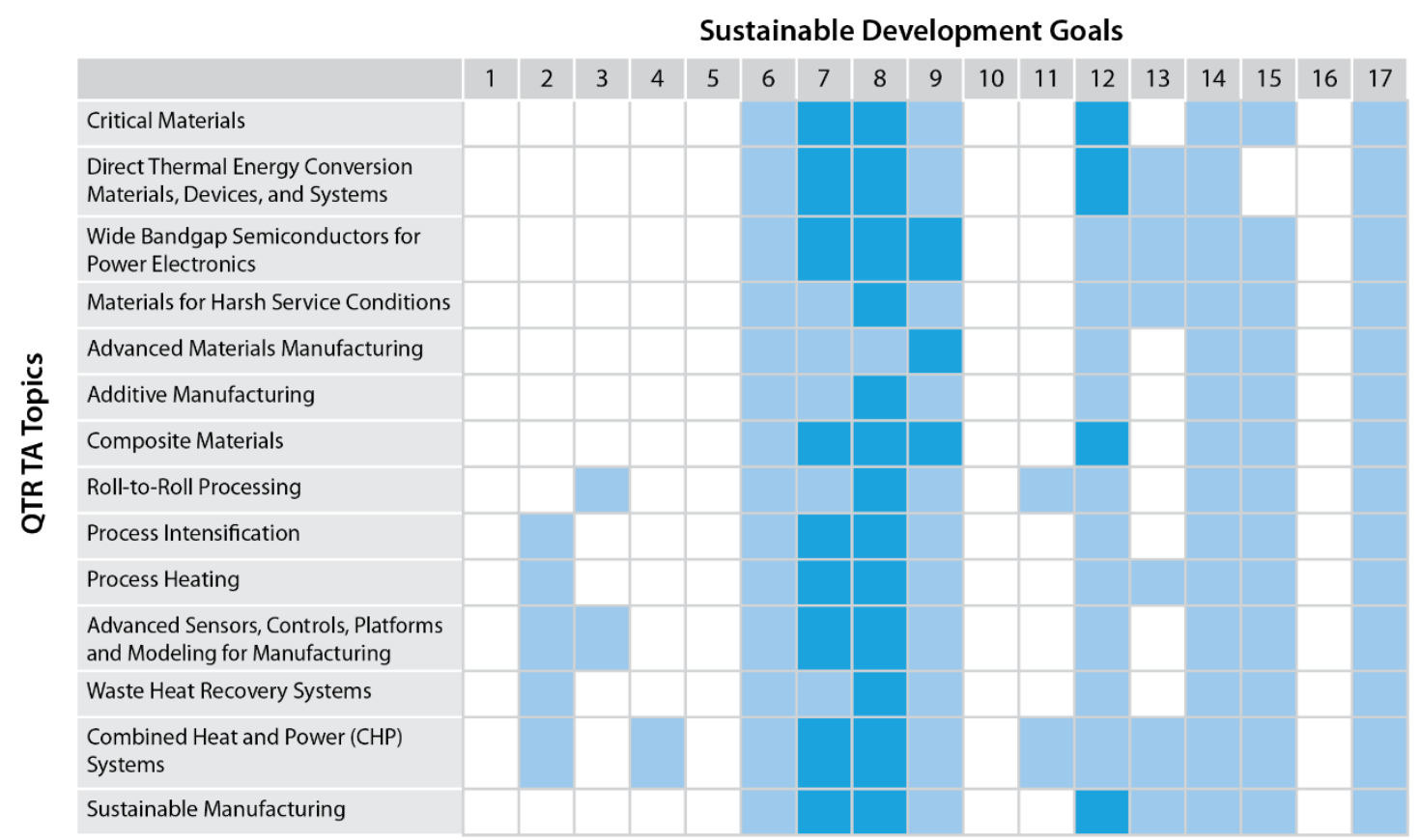

Figure 7. Heat map of relationships between draft MYPP and SDGs

The darker blue represents a direct relationship, the lighter blue represents a likely relationship, and the white means no relationship was clearly presented.

On the heat map, SDGs 7, 8, 9, and 12 had the most relationships to the TAs in the draft MYPP. SDGs 1, 5, 10, and 16 did not show any clear relationships but were all found represented in company reporting. SDGs 7, 8, and 12 are three of the most represented with companies and the 
SDGs with the most relationships to the MYPP. These overlap with the SDGs that PricewaterhouseCoopers said were most important to manufacturing, 7, 8, 9, 12, and 13.

On the existing federal SDG portal, 74 of the 169 targets had been reported online, and the rest were labeled as "exploring data sources," meaning they had not been reported yet and were not

Manufacturing and the SDGs
Bradken Tacoma Foundry
upgraded their air compressors,
so they are now able to move
twice the amount of air. The
foundry also replaced two older
noncycling dryers with cycling
dryers, saving them 235,000
kWh per year (Tacoma Power).
Bradken Tacoma Foundry is
working toward SDGs $7,8,9$,
and 12 .
in the process of being reported (U.S. Office of Management and Budget et al. n.d.). The 74 targets tracked by the federal portal were all last reported between 2012 and 2018. One of the 74 tracked targets was updated in 2018, so most of the tracked targets were updated between 2012 and 2017, with 2015, 2016, and 2017 as the most cited years of update. The sources of these targets' data came primarily from the U.S. Department of Commerce with 16 mentions, the U.S. Department of Education with 10 mentions, and the Center for Disease Control and Prevention with 9 mentions. Neither AMO nor DOE were mentioned a single time. These results and sources of data can be found in Appendix A2. 


\section{Discussion}

SDGs address societal needs and tie current actions to future benefits or harms. Failing to meet these goals exposes a company or organization to economic and operational risk because their future ability to produce their product or service could be compromised by environmental degradation (e.g., increases in the cost of clean water) or impair their social license to operate (e.g., loss of customers due to unsustainable policies or actions). Not all SDGs impact companies equally, however. It is important that the SDGs a company chooses to address align with the areas of highest impact for the company's operations and products. Additionally, concrete actions must be taken to meet the selected goals.

The analysis showed that SDGs related to energy or manufacturing are more likely to be cited. SDGs most relevant to meeting energy needs $(7,8,9,12$, and 13) were among most represented in company reporting, likely because the RDD\&D topics in the QTR Review focus on energyrelated technologies. As previously discussed, certain SDGs are easier to track or do better in, and that can lead to skewed reporting as well.

The SDGs represent topics that can impact companies on a day-to-day basis, such as infrastructure, energy, and production patterns. A company's vulnerability to disruption is exposure. Trucost evaluated exposure of the 2019 S\&P 500 companies to the topics represented within the SDGs by evaluating the economic flows and risk across supply chains and interactions with different sectors. They did not evaluate risk mitigation strategies. Their findings show companies are most exposed to business risks associated with SDGs 6 (clean water and sanitation), 13 (climate action), and 15 (life on land). Companies are exposed to SDG 6 because many have operations in arid regions or regions that will become dryer in the future. Failing to take climate action is a risk because of increased severe weather events, sea level rise, and the threat of carbon taxes. Companies are exposed to life on land because biodiversity and natural land loss are occurring at unprecedented rates. The SDGs cover a range of topics; therefore, Trucost found that companies are exposed to a range of topics that just so happen to coincide with similar topics found within the SDGs. Companies are not necessarily exposed to the SDGs, just topics that the SDGs cover.

One drawback of using company reporting as the main source of SDG representations is that not all companies perform sustainability reporting, even if they have sustainable policies or programs in place. However, if a company does not have sustainable policies in place, they cannot report on them at all. In 2019, the National Association of Manufacturers (NAM) conducted a survey of its 14,000 members across all 50 states (National Association of Manufacturers 2019). The members cross every aspect of the industrial sector, and their question was, "Does your company have a corporate responsibility or sustainability policy, program, and/or goals?" The results are in Figure 8. 


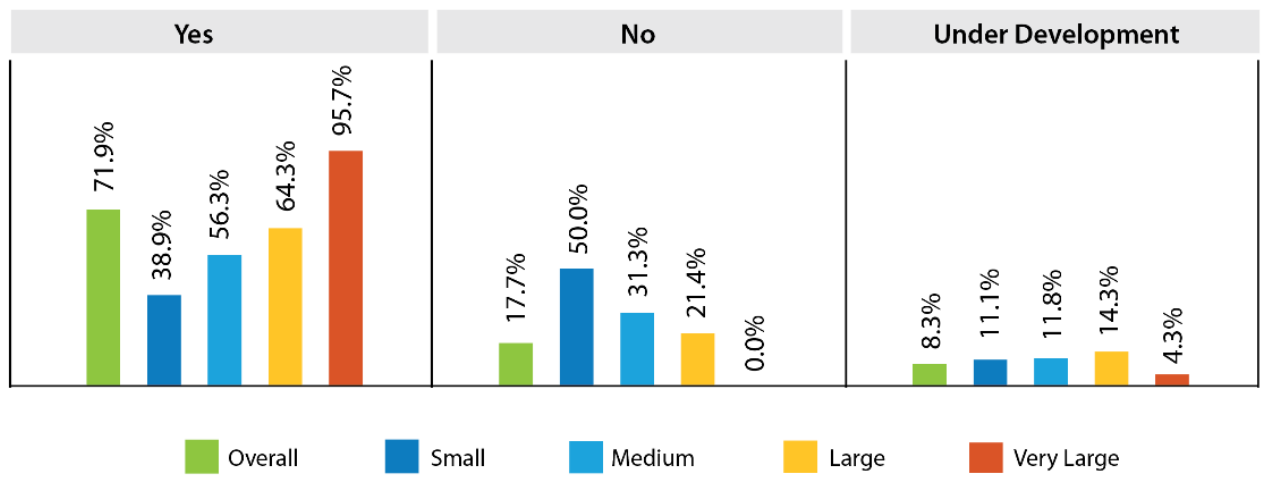

Figure 8. NAM results on sustainability reporting

Source: (National Association of Manufacturers 2019)

For reference, a small company had less than 100 employees, medium was 100 to 500 employees, large was 501 to 5,000 employees, and very large was more than 5,000 employees. Over $60 \%$ of small companies and almost $50 \%$ of medium companies did not have a sustainability plan or program in place. This work collected data from companies who had a sustainability program in place and then also chose to report their results. The companies who did not have a program in place or who reported on their results were not included in this study.

The same NAM report found the main business drivers for companies getting involved with sustainability included sustainability as their business model preference, market and consumer demands, customer demands, and government regulations. Those reasons are very similar to the reasons for SDG adoption, which include innovation and market development, efficiency and cost savings, reputation management, and risk reduction (Corporate Citizenship 2016).

While a general overview of sustainable manufacturing and the SDGs has been given, there is room for continued development. Future work involves providing the value proposition for manufacturing companies to adopt the SDGs, creating a method for easily integrating the SDGs into company reporting, and researching the connection between environmental justice and the SDGs. A comparison between the SDGs and MYPP targets can also be performed for other offices or MYPPs in different years.

\section{Manufacturing and the SDGs}

Trek introduced a new robotic painting system for their bikes that reduces the carbon footprint by over $90 \%$ in comparison to the previous painting process (Trek, 2021). With this work, Trek is incorporating SDGs 8, 9 , and 12 .
AMO is "dedicated to improving the energy and material efficiency, productivity, and competitiveness of manufacturers across the industrial sector" (Advanced Manufacturing Office 2021). Almost 30\% of NAM affiliates do not have a corporate sustainability program. There is an opportunity for AMO to not only further sustainable manufacturing efficiency, but to help manufacturers realize the $\$ 12$ trillion of market opportunities available when the SDGs are achieved (Business and Sustainable Development Commission 2017). 


\section{Conclusion}

Partnering the SDGs with the manufacturing sector will allow manufacturing companies to continue growing and address areas of improvement. The SDGs have actionable goals and metrics that allow companies - from start-ups to international corporations - to track and record their progress. The SDGs provide the foundation required to support DOE and AMO in creating a framework and resources needed to help make manufacturing companies more efficient, competitive, and productive. 


\section{Appendix}

\section{A.1 SDGs}

\section{Goal 1. End poverty in all its forms everywhere.}

1.1 By 2030, eradicate extreme poverty for all people everywhere, currently measured as people living on less than $\$ 1.25$ a day.

1.2 By 2030, reduce at least by half the proportion of men, women, and children of all ages living in poverty in all its dimensions according to national definitions.

1.3 Implement nationally appropriate social protection systems and measures for all, including floors, and by 2030 achieve substantial coverage of the poor and the vulnerable.

1.4 By 2030, ensure that all men and women, in particular the poor and the vulnerable, have equal rights to economic resources, as well as access to basic services, ownership and control over land and other forms of property, inheritance, natural resources, appropriate new technology, and financial services, including microfinance.

1.5 By 2030, build the resilience of the poor and those in vulnerable situations and reduce their exposure and vulnerability to climate-related extreme events and other economic, social, and environmental shocks and disasters.

1.a Ensure significant mobilization of resources from a variety of sources, including through enhanced development cooperation, in order to provide adequate and predictable means for developing countries, in particular least-developed countries, to implement programmes and policies to end poverty in all its dimensions.

1.b Create sound policy frameworks at the national, regional, and international levels, based on pro-poor and gender-sensitive development strategies, to support accelerated investment in poverty-eradication actions.

\section{Goal 2. End hunger, achieve food security and improved nutrition, and promote sustainable agriculture.}

2.1 By 2030, end hunger and ensure access by all people, in particular the poor and people in vulnerable situations, including infants, to safe, nutritious, and sufficient food all year round.

2.2 By 2030, end all forms of malnutrition, including achieving, by 2025 , the internationally agreed targets on stunting and wasting in children under 5 years of age, and address the nutritional needs of adolescent girls, pregnant and lactating women, and older persons.

2.3 By 2030, double the agricultural productivity and incomes of small-scale food producers, in particular women, indigenous peoples, family farmers, pastoralists, and fishers, including through secure and equal access to land, other productive resources and inputs, knowledge, financial services, markets, and opportunities for value addition and non-farm employment. 
2.4 By 2030, ensure sustainable food production systems and implement resilient agricultural practices that increase productivity and production, that help maintain ecosystems, that strengthen capacity for adaptation to climate change, extreme weather, drought, flooding, and other disasters, and that progressively improve land and soil quality.

2.5 By 2020, maintain the genetic diversity of seeds, cultivated plants, and farmed and domesticated animals and their related wild species, including through soundly managed and diversified seed and plant banks at the national, regional, and international levels, and promote access to and fair and equitable sharing of benefits arising from the utilization of genetic resources and associated traditional knowledge, as internationally agreed.

2.a Increase investment, including through enhanced international cooperation, in rural infrastructure, agricultural research and extension services, technology development and plant and livestock gene banks in order to enhance agricultural productive capacity in developing countries, in particular least developed countries.

2.b Correct and prevent trade restrictions and distortions in world agricultural markets, including through the parallel elimination of all forms of agricultural export subsidies and all export measures with equivalent effect, in accordance with the mandate of the Doha Development Round.

2.c Adopt measures to ensure the proper functioning of food commodity markets and their derivatives and facilitate timely access to market information, including on food reserves, in order to help limit extreme food price volatility.

\section{Goal 3. Ensure healthy lives and promote well-being for all at all ages.}

3.1 By 2030, reduce the global maternal mortality ratio to less than 70 per 100,000 live births.

3.2 By 2030, end preventable deaths of newborns and children under 5 years of age, with all countries aiming to reduce neonatal mortality to at least as low as 12 per 1,000 live births and under-5 mortality to at least as low as 25 per 1,000 live births.

3.3 By 2030, end the epidemics of AIDS, tuberculosis, malaria, and neglected tropical diseases and combat hepatitis, water-borne diseases, and other communicable diseases.

3.4 By 2030, reduce by one-third premature mortality from non-communicable diseases through prevention and treatment and promote mental health and wellbeing.

3.5 Strengthen the prevention and treatment of substance abuse, including narcotic drug abuse and harmful use of alcohol.

3.6 By 2020, halve the number of global deaths and injuries from road traffic accidents.

3.7 By 2030, ensure universal access to sexual and reproductive health care services, including for family planning, information and education, and the integration of reproductive health into national strategies and programmes. 
3.8 Achieve universal health coverage, including financial risk protection, access to quality essential health-care services and access to safe, effective, quality and affordable essential medicines and vaccines for all.

3.9 By 2030, substantially reduce the number of deaths and illnesses from hazardous chemicals and air, water and soil pollution, and contamination.

3.a Strengthen the implementation of the World Health Organization Framework Convention on Tobacco Control in all countries, as appropriate.

3.b Support the research and development of vaccines and medicines for the communicable and non-communicable diseases that primarily affect developing countries, provide access to affordable essential medicines and vaccines, in accordance with the Doha Declaration on the TRIPS Agreement and Public Health, which affirms the right of developing countries to use to the full the provisions in the Agreement on Trade-Related Aspects of Intellectual Property Rights regarding flexibilities to protect public health, and, in particular, provide access to medicines for all.

3.c Substantially increase health financing and the recruitment, development, training, and retention of the health workforce in developing countries, especially in least-developed countries and small island developing states.

3.d Strengthen the capacity of all countries, in particular developing countries, for early warning, risk reduction and management of national and global health risks.

\section{Goal 4. Ensure inclusive and equitable quality education and promote lifelong learning opportunities for all.}

4.1 By 2030, ensure that all girls and boys complete free, equitable, and quality primary and secondary education leading to relevant and effective learning outcomes.

4.2 By 2030, ensure that all girls and boys have access to quality early childhood development, care and pre-primary education so that they are ready for primary education.

4.3 By 2030, ensure equal access for all women and men to affordable and quality technical, vocational, and tertiary education, including university.

4.4 By 2030, substantially increase the number of youth and adults who have relevant skills, including technical and vocational skills, for employment, decent jobs, and entrepreneurship.

4.5 By 2030, eliminate gender disparities in education and ensure equal access to all levels of education and vocational training for the vulnerable, including persons with disabilities, indigenous peoples, and children in vulnerable situations.

4.6 By 2030, ensure that all youth and a substantial proportion of adults, both men and women, achieve literacy and numeracy. 
4.7 By 2030, ensure that all learners acquire the knowledge and skills needed to promote sustainable development, including, among others, through education for sustainable development and sustainable lifestyles, human rights, gender equality, promotion of a culture of peace and nonviolence, global citizenship. and appreciation of cultural diversity and of culture's contribution to sustainable development.

4.a Build and upgrade education facilities that are child, disability, and gender sensitive and provide safe, nonviolent, inclusive, and effective learning environments for all.

4.b By 2020, substantially expand globally the number of scholarships available to developing countries, in particular least developed countries, small island developing states and African countries, for enrollment in higher education, including vocational training and information and communications technology, technical, engineering and scientific programmes, in developed countries and other developing countries/

4.c By 2030, substantially increase the supply of qualified teachers, including through international cooperation for teacher training in developing countries, especially least developed countries and small island developing states.

\section{Goal 5. Achieve gender equality and empower all women and girls.}

\subsection{End all forms of discrimination against all women and girls everywhere.}

5.2 Eliminate all forms of violence against all women and girls in the public and private spheres, including trafficking and sexual and other types of exploitation.

5.3 Eliminate all harmful practices, such as child, early and forced marriage and female genital mutilation.

5.4 Recognize and value unpaid care and domestic work through the provision of public services, infrastructure and social protection policies and the promotion of shared responsibility within the household and the family as nationally appropriate.

5.5 Ensure women's full and effective participation and equal opportunities for leadership at all levels of decision-making in political, economic, and public life.

5.6 Ensure universal access to sexual and reproductive health and reproductive rights as agreed in accordance with the Programme of Action of the International Conference on Population and Development and the Beijing Platform for Action and the outcome documents of their review conferences.

5.a Undertake reforms to give women equal rights to economic resources, as well as access to ownership and control over land and other forms of property, financial services, inheritance, and natural resources, in accordance with national laws.

5.b Enhance the use of enabling technology, in particular information and communications technology, to promote the empowerment of women. 
5.c Adopt and strengthen sound policies and enforceable legislation for the promotion of gender equality and the empowerment of all women and girls at all levels.

\section{Goal 6. Ensure availability and sustainable management of water and sanitation for all.}

6.1 By 2030, achieve universal and equitable access to safe and affordable drinking water for all.

6.2 By 2030, achieve access to adequate and equitable sanitation and hygiene for all and end open defecation, paying special attention to the needs of women and girls and those in vulnerable situations.

6.3 By 2030, improve water quality by reducing pollution, eliminating dumping and minimizing release of hazardous chemicals and materials, halving the proportion of untreated wastewater and substantially increasing recycling and safe reuse globally.

6.4 By 2030, substantially increase water-use efficiency across all sectors and ensure sustainable withdrawals and supply of freshwater to address water scarcity and substantially reduce the number of people suffering from water scarcity.

6.5 By 2030, implement integrated water resources management at all levels, including through transboundary cooperation as appropriate.

6.6 By 2020, protect and restore water-related ecosystems, including mountains, forests, wetlands, rivers, aquifers, and lakes.

6.a By 2030, expand international cooperation and capacity-building support to developing countries in water- and sanitation-related activities and programmes, including water harvesting, desalination, water efficiency, wastewater treatment, recycling and reuse technologies.

6.b Support and strengthen the participation of local communities in improving water and sanitation management,

Goal 7. Ensure access to affordable, reliable, sustainable, and modern energy for all.

7.1 By 2030, ensure universal access to affordable, reliable, and modern energy services.

7.2 By 2030, increase substantially the share of renewable energy in the global energy mix.

7.3 By 2030, double the global rate of improvement in energy efficiency.

7.a By 2030, enhance international cooperation to facilitate access to clean energy research and technology, including renewable energy, energy efficiency and advanced and cleaner fossil-fuel technology, and promote investment in energy infrastructure and clean energy technology.

7.b By 2030, expand infrastructure and upgrade technology for supplying modern and sustainable energy services for all in developing countries, in particular least-developed countries, small island developing states and landlocked developing countries, in accordance with their respective programmes of support. 
Goal 8. Promote sustained, inclusive, and sustainable economic growth, full and productive employment and decent work for all.

8.1 Sustain per capita economic growth in accordance with national circumstances and, in particular, at least 7\% gross domestic product growth per annum in the least developed countries.

8.2 Achieve higher levels of economic productivity through diversification, technological upgrading and innovation, including through a focus on high-value added and labour-intensive sectors.

8.3 Promote development-oriented policies that support productive activities, decent job creation, entrepreneurship, creativity and innovation, and encourage the formalization and growth of micro-, small- and medium-sized enterprises, including through access to financial services.

8.4 Improve progressively, through 2030, global resource efficiency in consumption and production and endeavour to decouple economic growth from environmental degradation, in accordance with the 10-Year Framework of Programmes on Sustainable Consumption and Production, with developed countries taking the lead.

8.5 By 2030, achieve full and productive employment and decent work for all women and men, including for young people and persons with disabilities, and equal pay for work of equal value.

8.6 By 2020, substantially reduce the proportion of youth not in employment, education, or training.

8.7 Take immediate and effective measures to eradicate forced labour, end modern slavery and human trafficking, and secure the prohibition and elimination of the worst forms of child labour, including recruitment and use of child soldiers, and by 2025 end child labour in all its forms.

8.8 Protect labour rights and promote safe and secure working environments for all workers, including migrant workers, in particular women migrants, and those in precarious employment.

8.9 By 2030, devise and implement policies to promote sustainable tourism that creates jobs and promotes local culture and products.

8.10 Strengthen the capacity of domestic financial institutions to encourage and expand access to banking, insurance and financial services for all.

8.a Increase Aid for Trade support for developing countries, in particular least-developed countries, including through the Enhanced Integrated Framework for Trade-related Technical Assistance to Least Developed Countries.

8.b By 2020, develop and operationalize a global strategy for youth employment and implement the Global Jobs Pact of the International Labour Organization.

Goal 9. Build resilient infrastructure, promote inclusive and sustainable industrialization, and foster innovation. 
9.1 Develop quality, reliable, sustainable, and resilient infrastructure, including regional and transborder infrastructure, to support economic development and human well-being, with a focus on affordable and equitable access for all.

9.2 Promote inclusive and sustainable industrialization and, by 2030, significantly raise industry's share of employment and gross domestic product, in line with national circumstances, and double its share in least developed countries.

9.3 Increase the access of small-scale industrial and other enterprises, in particular in developing countries, to financial services, including affordable credit, and their integration into value chains and markets.

9.4 By 2030, upgrade infrastructure and retrofit industries to make them sustainable, with increased resource-use efficiency and greater adoption of clean and environmentally sound technologies and industrial processes, with all countries taking action in accordance with their respective capabilities.

9.5 Enhance scientific research, upgrade the technological capabilities of industrial sectors in all countries, in particular developing countries, including, by 2030, encouraging innovation and substantially increasing the number of research and development workers per 1 million people and public and private research and development spending.

9.a Facilitate sustainable and resilient infrastructure development in developing countries through enhanced financial, technological, and technical support to African countries, leastdeveloped countries, landlocked developing countries and small island developing states.

9.b Support domestic technology development, research and innovation in developing countries, including by ensuring a conducive policy environment for, inter alia, industrial diversification and value addition to commodities.

9.c Significantly increase access to information and communications technology and strive to provide universal and affordable access to the internet in least-developed countries by 2020 .

\section{Goal 10. Reduce inequality within and among countries.}

10.1 By 2030, progressively achieve and sustain income growth of the bottom $40 \%$ of the population at a rate higher than the national average.

10.2 By 2030, empower and promote the social, economic, and political inclusion of all, irrespective of age, sex, disability, race, ethnicity, origin, religion, or economic or other status.

10.3 Ensure equal opportunity and reduce inequalities of outcome, including by eliminating discriminatory laws, policies, and practices and promoting appropriate legislation, policies, and action in this regard.

10.4 Adopt policies, especially fiscal, wage, and social protection policies, and progressively achieve greater equality. 
10.5 Improve the regulation and monitoring of global financial markets and institutions and strengthen the implementation of such regulations.

10.6 Ensure enhanced representation and voice for developing countries in decision-making in global international economic and financial institutions in order to deliver more effective, credible, accountable, and legitimate institutions.

10.7 Facilitate orderly, safe, regular, and responsible migration and mobility of people, including through the implementation of planned and well-managed migration policies.

10.a Implement the principle of special and differential treatment for developing countries, in particular least-developed countries, in accordance with World Trade Organization agreements.

10.b Encourage official development assistance and financial flows, including foreign direct investment, to states where the need is greatest, in particular least-developed countries, African countries, small island developing states and landlocked developing countries, in accordance with their national plans and programmes.

10.c By 2030, reduce to less than $3 \%$ the transaction costs of migrant remittances and eliminate remittance corridors with costs higher than $5 \%$.

Goal 11. Make cities and human settlements inclusive, safe, resilient, and sustainable.

11.1 By 2030, ensure access for all to adequate, safe, and affordable housing and basic services and upgrade slums.

11.2 By 2030, provide access to safe, affordable, accessible, and sustainable transport systems for all, improving road safety, notably by expanding public transport, with special attention to the needs of those in vulnerable situations, women, children, persons with disabilities, and older persons.

11.3 By 2030, enhance inclusive and sustainable urbanization and capacity for participatory, integrated, and sustainable human settlement planning and management in all countries.

11.4 Strengthen efforts to protect and safeguard the world's cultural and natural heritage.

11.5 By 2030, significantly reduce the number of deaths and the number of people affected and substantially decrease the direct economic losses relative to global gross domestic product caused by disasters, including water-related disasters, with a focus on protecting the poor and people in vulnerable situations.

11.6 By 2030, reduce the adverse per capita environmental impact of cities, including by paying special attention to air quality and municipal and other waste management.

11.7 By 2030, provide universal access to safe, inclusive, and accessible, green, and public spaces, in particular for women and children, older persons, and persons with disabilities. 
11.a Support positive economic, social and environmental links between urban, peri-urban, and rural areas by strengthening national and regional development planning.

11.b By 2020, substantially increase the number of cities and human settlements adopting and implementing integrated policies and plans towards inclusion, resource efficiency, mitigation and adaptation to climate change, resilience to disasters, and develop and implement, in line with the Sendai Framework for Disaster Risk Reduction 2015-2030, holistic disaster risk management at all levels.

11.c Support least-developed countries, including through financial and technical assistance, in building sustainable and resilient buildings utilizing local materials.

\section{Goal 12. Ensure sustainable consumption and production patterns.}

12.1 Implement the 10-Year Framework of Programmes on Sustainable Consumption and Production Patterns, all countries taking action, with developed countries taking the lead, taking into account the development and capabilities of developing countries.

12.2 By 2030, achieve the sustainable management and efficient use of natural resources.

12.3 By 2030, halve per capita global food waste at the retail and consumer levels and reduce food losses along production and supply chains, including post-harvest losses.

12.4 By 2020, achieve the environmentally sound management of chemicals and all wastes throughout their life cycle, in accordance with agreed international frameworks, and significantly reduce their release to air, water, and soil in order to minimize their adverse impacts on human health and the environment.

12.5 By 2030, substantially reduce waste generation through prevention, reduction, recycling, and reuse.

12.6 Encourage companies, especially large and transnational companies, to adopt sustainable practices and to integrate sustainability information into their reporting cycle.

12.7 Promote public procurement practices that are sustainable, in accordance with national policies and priorities.

12.8 By 2030, ensure that people everywhere have the relevant information and awareness for sustainable development and lifestyles in harmony with nature.

12.a Support developing countries to strengthen their scientific and technological capacity to move towards more sustainable patterns of consumption and production.

12.b Develop and implement tools to monitor sustainable development impacts for sustainable tourism that creates jobs and promotes local culture and products.

12.c Rationalize inefficient fossil-fuel subsidies that encourage wasteful consumption by removing market distortions, in accordance with national circumstances, including by 
restructuring taxation and phasing out those harmful subsidies, where they exist, to reflect their environmental impacts, taking fully into account the specific needs and conditions of developing countries and minimizing the possible adverse impacts on their development in a manner that protects the poor and the affected communities.

\section{Goal 13. Take urgent action to combat climate change and its impacts.}

13.1 Strengthen resilience and adaptive capacity to climate-related hazards and natural disasters in all countries.

13.2 Integrate climate change measures into national policies, strategies, and planning.

13.3 Improve education, awareness-raising and human and institutional capacity on climate change mitigation, adaptation, impact reduction, and early warning.

13.a Implement the commitment undertaken by developed-country parties to the United Nations Framework Convention on Climate Change to a goal of mobilizing jointly $\$ 100$ billion annually by 2020 from all sources to address the needs of developing countries in the context of meaningful mitigation actions and transparency on implementation and fully operationalize the Green Climate Fund through its capitalization as soon as possible.

13.b Promote mechanisms for raising capacity for effective climate change-related planning and management in least-developed countries and small island developing states, including focusing on women, youth and local and marginalized communities.

\section{Goal 14. Conserve and sustainably use the oceans, seas, and marine resources for sustainable development.}

14.1 By 2025, prevent and significantly reduce marine pollution of all kinds, in particular from land-based activities, including marine debris and nutrient pollution.

14.2 By 2020, sustainably manage and protect marine and coastal ecosystems to avoid significant adverse impacts, including by strengthening their resilience, and take action for their restoration in order to achieve healthy and productive oceans.

14.3 Minimize and address the impacts of ocean acidification, including through enhanced scientific cooperation at all levels.

14.4 By 2020, effectively regulate harvesting and end overfishing, illegal, unreported, and unregulated fishing and destructive fishing practices and implement science-based management plans, in order to restore fish stocks in the shortest time feasible, at least to levels that can produce maximum sustainable yield as determined by their biological characteristics.

14.5 By 2020, conserve at least $10 \%$ of coastal and marine areas, consistent with national and international law and based on the best available scientific information.

14.6 By 2020, prohibit certain forms of fisheries subsidies which contribute to overcapacity and overfishing, eliminate subsidies that contribute to illegal, unreported, and unregulated fishing and 
refrain from introducing new such subsidies, recognizing that appropriate and effective special and differential treatment for developing and least developed countries should be an integral part of the World Trade Organization fisheries subsidies negotiation.

14.7 By 2030, increase the economic benefits to small island developing states and leastdeveloped countries from the sustainable use of marine resources, including through sustainable management of fisheries, aquaculture and tourism.

14.a Increase scientific knowledge, develop research capacity and transfer marine technology, taking into account the Intergovernmental Oceanographic Commission Criteria and Guidelines on the Transfer of Marine Technology, in order to improve ocean health and to enhance the contribution of marine biodiversity to the development of developing countries, in particular small island developing states and least-developed countries.

14.b Provide access for small-scale artisanal fishers to marine resources and markets.

14.c Enhance the conservation and sustainable use of oceans and their resources by implementing international law as reflected in the United Nations Convention on the Law of the Sea, which provides the legal framework for the conservation and sustainable use of oceans and their resources, as recalled in paragraph 158 of "The future we want."

Goal 15. Protect, restore, and promote sustainable use of terrestrial ecosystems, sustainably manage forests, combat desertification, and halt and reverse land degradation and halt biodiversity loss.

15.1 By 2020, ensure the conservation, restoration, and sustainable use of terrestrial and inland freshwater ecosystems and their services, in particular forests, wetlands, mountains, and drylands, in line with obligations under international agreements.

15.2 By 2020, promote the implementation of sustainable management of all types of forests, halt deforestation, restore degraded forests, and substantially increase afforestation and reforestation globally.

15.3 By 2030, combat desertification, restore degraded land and soil, including land affected by desertification, drought and floods, and strive to achieve a land degradation-neutral world.

15.4 By 2030, ensure the conservation of mountain ecosystems, including their biodiversity, in order to enhance their capacity to provide benefits that are essential for sustainable development.

15.5 Take urgent and significant action to reduce the degradation of natural habitats, halt the loss of biodiversity and, by 2020, protect and prevent the extinction of threatened species.

15.6 Promote fair and equitable sharing of the benefits arising from the utilization of genetic resources and promote appropriate access to such resources, as internationally agreed.

15.7 Take urgent action to end poaching and trafficking of protected species of flora and fauna and address both demand and supply of illegal wildlife products. 
15.8 By 2020, introduce measures to prevent the introduction and significantly reduce the impact of invasive alien species on land and water ecosystems and control or eradicate the priority species.

15.9 By 2020, integrate ecosystem and biodiversity values into national and local planning, development processes, poverty reduction strategies, and accounts.

15.a Mobilize and significantly increase financial resources from all sources to conserve and sustainably use biodiversity and ecosystems.

15.b Mobilize significant resources from all sources and at all levels to finance sustainable forest management and provide adequate incentives to developing countries to advance such management, including for conservation and reforestation.

15.c Enhance global support for efforts to combat poaching and trafficking of protected species, including by increasing the capacity of local communities to pursue sustainable livelihood opportunities.

Goal 16. Promote peaceful and inclusive societies for sustainable development, provide access to justice for all and build effective, accountable, and inclusive institutions at all levels.

16.1 Significantly reduce all forms of violence and related death rates everywhere.

16.2 End abuse, exploitation, trafficking, and all forms of violence against and torture of children.

16.3 Promote the rule of law at the national and international levels and ensure equal access to justice for all.

16.4 By 2030, significantly reduce illicit financial and arms flows, strengthen the recovery and return of stolen assets, and combat all forms of organized crime.

16.5 Substantially reduce corruption and bribery in all their forms

16.6 Develop effective, accountable, and transparent institutions at all levels.

16.7 Ensure responsive, inclusive, participatory, and representative decision-making at all levels.

16.8 Broaden and strengthen the participation of developing countries in the institutions of global governance.

16.9 By 2030, provide legal identity for all, including birth registration.

16.10 Ensure public access to information and protect fundamental freedoms, in accordance with national legislation and international agreements. 
16.a Strengthen relevant national institutions, including through international cooperation, for building capacity at all levels, in particular in developing countries, to prevent violence and combat terrorism and crime.

16.b Promote and enforce nondiscriminatory laws and policies for sustainable development.

\section{Goal 17. Strengthen the means of implementation and revitalize the Global Partnership for Sustainable Development Finance.}

17.1 Strengthen domestic resource mobilization, including through international support to developing countries, to improve domestic capacity for tax and other revenue collection.

17.2 Developed countries to implement fully their official development assistance commitments, including the commitment by many developed countries to achieve the target of 0.7 per cent of gross national income for official development assistance (ODA/GNI) to developing countries and 0.15 to 0.20 per cent of ODA/GNI to least developed countries; ODA providers are encouraged to consider setting a target to provide at least $0.20 \%$ of ODA/GNI to least developed countries.

17.3 Mobilize additional financial resources for developing countries from multiple sources.

17.4 Assist developing countries in attaining long-term debt sustainability through coordinated policies aimed at fostering debt financing, debt relief and debt restructuring, as appropriate, and address the external debt of highly indebted poor countries to reduce debt distress.

17.5 Adopt and implement investment promotion regimes for least-developed countries.

\section{Technology}

17.6 Enhance North-South, South-South, and triangular regional and international cooperation on and access to science, technology, and innovation, and enhance knowledge sharing on mutually agreed terms, including through improved coordination among existing mechanisms, in particular at the United Nations level, and through a global technology facilitation mechanism.

17.7 Promote the development, transfer, dissemination, and diffusion of environmentally sound technologies to developing countries on favourable terms, including on concessional and preferential terms, as mutually agreed.

17.8 Fully operationalize the technology bank and science, technology and innovation capacitybuilding mechanism for least developed countries by 2017 and enhance the use of enabling technology, in particular information and communications technology.

\section{Capacity-Building}

17.9 Enhance international support for implementing effective and targeted capacity-building in developing countries to support national plans to implement all the Sustainable Development Goals, including through North-South, South-South, and triangular cooperation. 


\section{Trade}

17.10 Promote a universal, rules-based, open, nondiscriminatory, and equitable multilateral trading system under the World Trade Organization, including through the conclusion of negotiations under its Doha Development Agenda.

17.11 Significantly increase the exports of developing countries, in particular with a view to doubling the least developed countries' share of global exports by 2020 .

17.12 Realize timely implementation of duty-free and quota-free market access on a lasting basis for all least developed countries, consistent with World Trade Organization decisions, including by ensuring that preferential rules of origin applicable to imports from least-developed countries are transparent and simple, and contribute to facilitating market access.

\section{Systemic Issues}

\section{Policy and institutional coherence}

17.13 Enhance global macro-economic stability, including through policy coordination and policy coherence.

17.14 Enhance policy coherence for sustainable development.

17.15 Respect each country's policy space and leadership to establish and implement policies for poverty eradication and sustainable development.

\section{Multi-stakeholder partnerships}

17.16 Enhance the Global Partnership for Sustainable Development, complemented by multistakeholder partnerships that mobilize and share knowledge, expertise, technology and financial resources, to support the achievement of the Sustainable Development Goals in all countries, in particular developing countries.

17.17 Encourage and promote effective public, public-private, and civil society partnerships, building on the experience and resourcing strategies of partnerships.

\section{Data, monitoring and accountability}

17.18 By 2020, enhance capacity-building support to developing countries, including for leastdeveloped countries and small island developing states, to increase significantly the availability of high-quality, timely and reliable data disaggregated by income, gender, age, race, ethnicity, migratory status, disability, geographic location, and other characteristics relevant in national contexts.

17.19 By 2030, build on existing initiatives to develop measurements of progress on sustainable development that complement gross domestic product, and support statistical capacity-building in developing countries. 


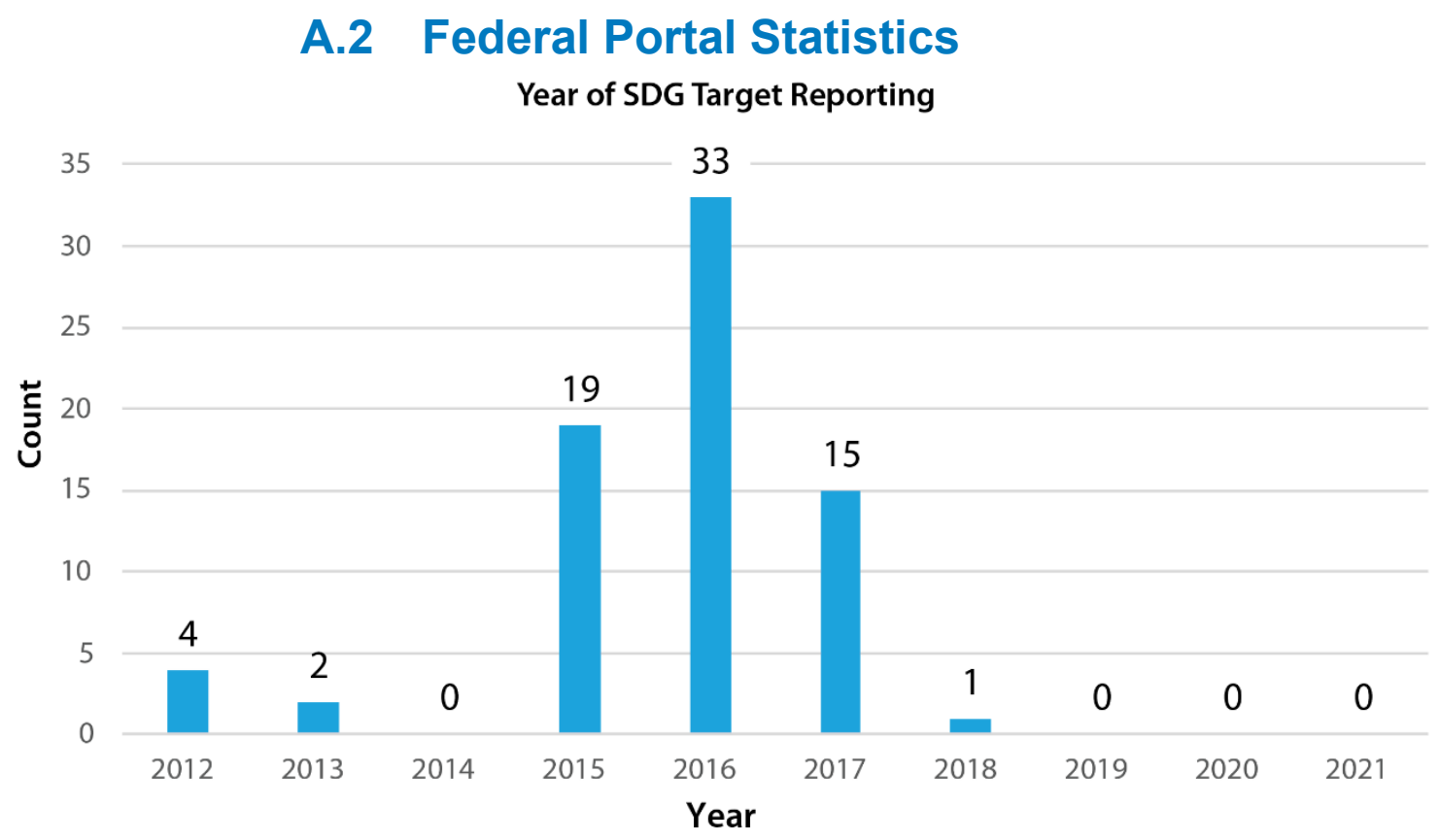

Figure A- 1 Year each SDG target was last reported

\section{Source of SDG Target data}

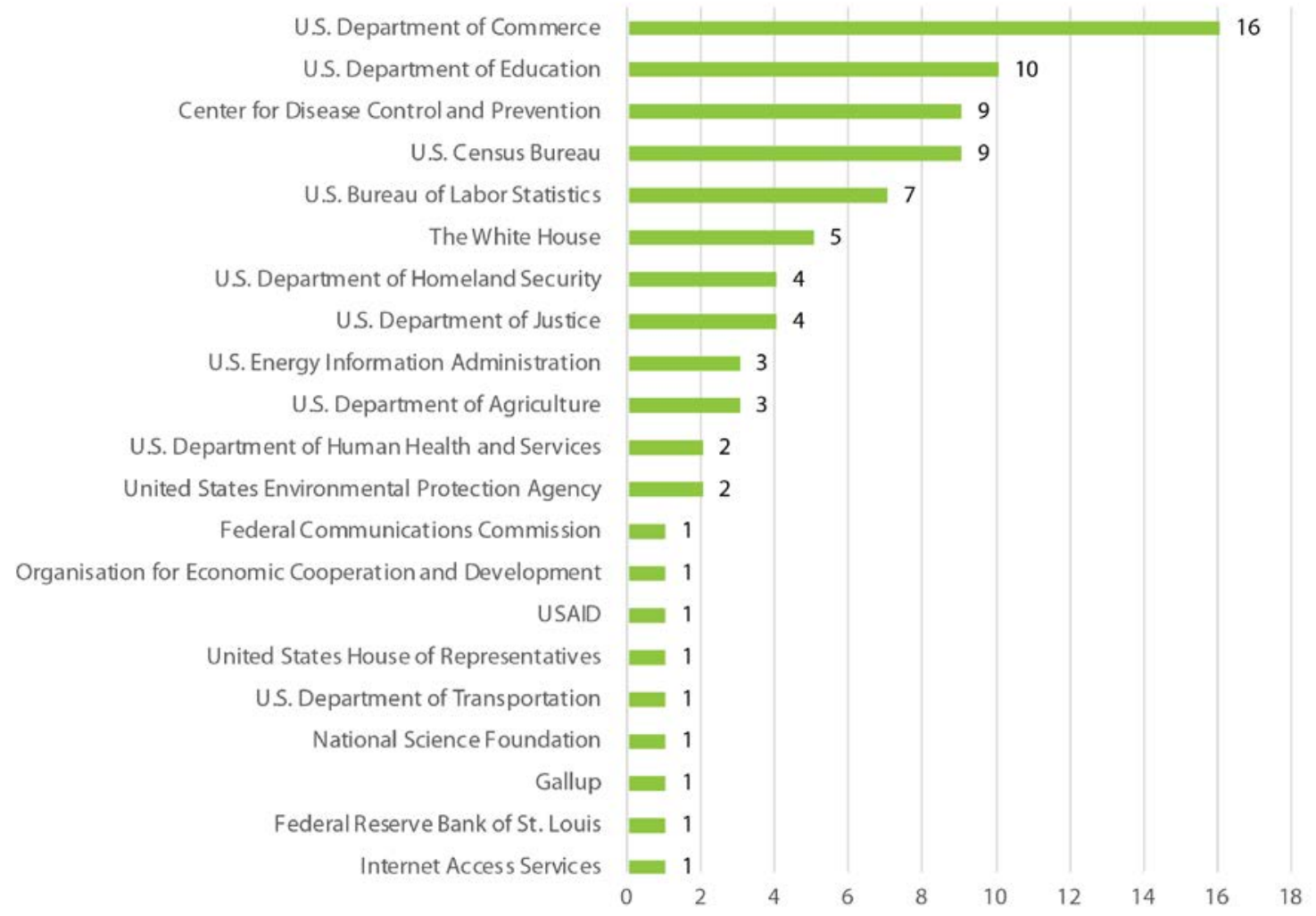

Figure A- 2 Source of data for SDG target reporting 


\section{References}

Advanced Manufacturing Office. (2016). Multi-Year Program Plan for Fiscal Years 2017 through 2021 Draft.

https://www.energy.gov/sites/default/files/2017/01/f34/Draft\%20Advanced\%20Manufact uring\%200ffice\%20MYPP_1.pdf

Advanced Manufacturing Office. (2021). About us. https://www.energy.gov/eere/amo/about-us

Alcoa. (2020). 2020 Sustainability Report. Retrieved from https://www.alcoa.com/sustainability/en/pdf/2020-Sustainability-Report.pdf

Art, J.-Y., \& Emejulu, D. A. (2020). Microsoft and the United Nations Sustainable Development Goals. https://www.microsoft.com/en-us/corporate-responsibility/un-sustainabledevelopment-goals

Business and Sustainable Development Commission. (2017). Better Business, Better World. 122.

Chapa, J. (n.d.). Interconnection instead of isolation: A new world of sustainable development. World Green Building Council. Retrieved September 20, 2021, from https://www.worldgbc.org/news-media/interconnection-instead-isolation-new-worldsustainable-development

Chien, Y., \& Morris, P. (2017, April). Is U.S. Manufacturing Really Declining? https://www.stlouisfed.org/on-the-economy/2017/april/us-manufacturing-really-declining

Corporate Citizenship. (2016). SDGs \& Sectors: A review of the business opportunities. $\mathrm{http} / / / \mathrm{s} 3$.amazonaws.com/aws-bsdc/SDG-Sectors.pdf

Cummins Inc. (2021). 2020 sustainability progress report. https://www.cummins.com/sites/default/files/2021-06/202021_cummins_sustainability_report.pdf

Ford. (2020). Sustainability Report 2020.

GE. (2021). 2020 sustainability report. https://www.ge.com/sites/default/files/ge2020_sustainability_report.pdf

Hak, T., Janouskova, S., \& Moldan, B. (2016). Sustainable Development Goals: A need for relevant indicators. Ecological Indicators, 60, 565-573. https://doi.org/10.1016/j.ecolind.2015.08.003

Harris, K., \& McCall, M. (2019, December). The relative weakness in earnings of production workers in manufacturing, 1990-2018. https://www.bls.gov/opub/mlr/2019/article/earnings-of-production-workers-inmanufacturing-1990-2018.htm

Ike, M., Donovan, J. D., Topple, C., \& Masli, E. K. (2019). The process of selecting and prioritising corporate sustainability issues: Insights for achieving the Sustainable Development Goals. Journal of Cleaner Production, 236, 117661. https://doi.org/10.1016/j.jclepro.2019.117661

Johnsson, F., Karlsson, I., Rootzen, J., Ahlback, A., \& Gustavsson, M. (2020). The framing of a sustainable development goals assessment in decarbonizing the construction industry Avoiding "Greenwashing." Renewable and Sustainable Energy Reviews, 131. https://doi.org/10.1016/j.rser.2020.110029

Kennedy, S. (2020, October 21). 6 case studies illuminate the value of predictive and prescriptive maintenance. Retrieved from https://www.plantservices.com/articles/2020/6case-studies-illuminate-the-value-of-predictive-and-prescriptive-maintenance/ 
Khan, P. A., Johl, S. K., \& Johl, S. K. (2021). Does adoption of ISO 56002-2019 and green innovation reporting enhance the firm sustainable development goal performance? An emerging paradigm. Business Strategy and the Environment, $n / a(\mathrm{n} / \mathrm{a})$. https://doi.org/10.1002/bse.2779

Miola, A., \& Schiltz, F. (2019). Measuring sustainable development goals performance: How to monitor policy action in the 2030 Agenda implementation? Ecological Economics, 164, 106373. https://doi.org/10.1016/j.ecolecon.2019.106373

Naidoo, R., \& Fisher, B. (2020). Reset Sustainable Development Goals for a pandemic world. Nature, 583(7815), 198-201. https://doi.org/10.1038/d41586-020-01999-x

National Association of Manufacturers. (2019). Manufacturing's commitment to sustainability. https://www.nam.org/wp-content/uploads/2019/07/NAM-Sustainability-Survey-Report2019.pdf

Oli Systems, Inc. (2018). Breakthrough in REE and aqueous sulfate chemistry simulation. Retrieved from REE and Aqueous Sulfate: https://www.olisystems.com/cmi-nist

Prakash, M., Teksoz, K., Espey, J., Sachs, J., Shank, M., \& Schmidt-Traub, G. (2017). Achieving a sustainable urban America. https://irpcdn.multiscreensite.com/be6d1d56/files/uploaded/US-Cities-SDG-Index-2017.pdf

PwC. (2017). Delivering the Sustainable Development Goals. https://www.pwc.com/co/es/assets/document/delivering-sustainable-developmentgoals.pdf

Schroeder, P., Anggraeni, K., \& Weber, U. (2019). The Relevance of Circular Economy Practices to the Sustainable Development Goals. Journal of Industrial Ecology, 23(1), 77-95. https://doi.org/10.1111/jiec.12732

Rev Group, Inc. (2020). 2020 Sustainability Report.

Reynolds, P. (2018, September 18). Febreze a Dow award finalist. Retrieved from https://www.packworld.com/design/materials-containers/article/13375852/febreze-adow-award-finalist

SDSN. (n.d.). Tools for SDG achievement. SDSN Northern Europe. Retrieved August 27, 2021, from https://www.unsdsn-ne.org/our-actions/tools-for-assessing-sdg-achievement/

Tacoma Power. (n.d.). Compressed air efficiency. Retrieved from https://www.mytpu.org/wpcontent/uploads/bradken-case-study.pdf

Trek. (2021). Waste Reduction. Retrieved from https:/www.trekbikes.com/us/en_US/company/sustainability/waste_reduction/

TURI and OTA. (2017). Toxics use reduction and resource conservation: competitiveness impacts for Massachusetts Business.

United Nations. (n.d.). The 17 Goals. Retrieved September 27, 2021, from https://sdgs.un.org/goals

United Nations. (2021a). SDGs Sustainable Development Knowledge Platform. https://sustainabledevelopment.un.org/topics/sustainabledevelopmentgoals

United Nations. (2021b). The sustainable development agenda. https://www.un.org/sustainabledevelopment/development-agenda/

United States Environmental Protection Agency. (2020, December 7). Sustainable manufacturing. https://www.epa.gov/sustainability/sustainable-manufacturing

United States Geological Survey. (2015). Industrial Water Use. https://www.usgs.gov/missionareas/water-resources/science/industrial-water-use?qt-science_center_objects=0\#qtscience_center_objects 
U.S. Bureau of Economic Analysis. (n.d.). Employment by Industry. Retrieved November 4, 2021, from https://www.bea.gov/data/employment/employment-by-industry

U.S. Bureau of Economic Analysis. (2021). What is gross output by industry and how does it differ from gross domestic product (or value added) by industry. https://www.bea.gov/help/faq/1197

U.S. Department of Energy. (2015a). Quadrennial Technology Review 2015. https://www.energy.gov/sites/prod/files/2017/03/f34/quadrennial-technology-review2015_1.pdf

U.S. Department of Energy. (2015b). Quadrennial technology review 2015, chapter 6: Innovating clean energy technologies in advanced manufacturing, 6. L sustainable manufacturing - Flow of materials through industry. https://www.energy.gov/sites/prod/files/2016/05/f31/QTR2015-6L-SustainableManufacturing.pdf

U.S. Department of Energy. (2021a). About us. https://www.energy.gov/about-us

U.S. Department of Energy. (2021b). History and Impacts. Energy.Gov. https://www.energy.gov/eere/buildings/history-and-impacts

U.S. Department of Energy. (2021c). The Quadrennial Technology Review. https://www.energy.gov/quadrennial-technology-review-0

U.S. Energy Information Administration. (n.d.). Glossary. Retrieved August 31, 2021, from https://www.eia.gov/tools/glossary/index.php

U.S. Energy Information Administration. (2021a, May 20). Renewable energy explained. https:/www.eia.gov/energyexplained/renewable-sources/

U.S. Energy Information Administration. (2021b, August 26). Total Energy. https://www.eia.gov/totalenergy/data/browser/index.php?tbl=T02.04\#/?f=A\&start=1949 \&end=2020\&charted=2-3-4-12-14

U.S. Environmental Protection Agency. (2021). Greenhouse Gas Inventory Data Explorer. https://cfpub.epa.gov/ghgdata/inventoryexplorer/index.html

U.S. Office of Management and Budget, Office of Information and Regulatory Affairs, U.S. Department of State, Office of International Organizations, U.S. General Services Administration, \& U.S. Office of Science and Technology Policy. (n.d.). U.S. Indicators For The Sustainable Development Goals. Retrieved August 24, 2021, from https://sdg.data.gov/reporting-status/

World Commission on Environment and Development. (1987). Our Common Future. Oxford: Oxford University Press. 